DOI: $10.4274 /$ tpa.715

\title{
Transanal protrusion of ventriculo-peritoneal shunt related to colon perforation: Two case reports
}

\author{
Ahmet Hakan Gedik1, Selçuk Uzuner2, Ergül Cindemir2, Süleyman Bayraktar1, \\ Emel Torun2, Hakan Seyithanoğlu2, Hüseyin Kılınçaslan4,Metin Karaböcüoğlu1 \\ ${ }^{1}$ Bezmialem Vakıf University, Medical Faculty, Department of Pediatrics, Pediatric Intensive care Unit, Istanbul, Turkey \\ 2Bezmialem Vakif University, Medical Faculty, Department of Pediatrics, Istanbul, Turkey \\ ${ }^{3}$ Bezmialem Vakif University, Medical Faculty, Department of Neurosurgery, Istanbul, Turkey \\ ${ }^{4}$ Bezmialem Vakıf University, Medical Faculty, Department of Pediatric Surgery, Istanbul, Turkey
}

\section{Summary}

Hydrocephalus represents a diverse group of conditions that are characterized with dilatation of the ventricular system and increased cerebrospinal fluid pressure. Ventriculo-peritoneal shunt placement is a commonly used treatment method for hydrocephalus for diverting the cerebrospinal fluid into the peritoneal cavity. The most common complication of ventriculo-peritoneal shunt is dysfunction of the shunt mainly due to catheter obstruction or infection. Spontaneous bowel perforation is a rare complication of ventriculoperitoneal shunt. This article aims to discuss ventriculo-peritoneal shunt complications and the significance of colon perforation among these complications by presenting two cases of anal protrusion of ventriculoperitoneal shunt catheter that is inserted in order to reduce the hydrocephalus detected in the neonatal period. (Turk Arch Ped 2013; 48: 255-258)

Key words: Child, colon perforation, transanal protrusion, ventriculo-peritoneal shunt

\section{Introduction}

Hydrocephalus may be defined as enlargement of the ventricles and increase in CSF pressure which arises from any problem in production, circulation and absorption of the cerebrospinal fluid (CSF) $(1,2)$. Since prolonged increased intracranial pressure and enlarged ventricles may disrupt neuronal development, treatment of hydrocephalus found in the neonate is of vital importance. The most commonly performed method to improve the flow of CSF is discharging of CSF into the peritoneum by way of a ventriculoperitoneal (VP) shunt (3).

The most common complication in use of shunt in patients with hydrocephalus include shunt dysfunction and related clinical pictures (4). Complications develop more frequently in children compared to adults. Interesting complications include migration of the shunt to the genitourinary system (bladder, vagina, ureter), gastrointestinal tract (stomach, colon), thorax and even heart by exceeding the diaphram and migration outside the abdomen through the incision places and umbilicus (5). Bowel perforation related with shunt is observed rarely and transanal protrusion of the catheter may also be observed $(6,7,8,9,10)$.

In this article, we present two patients in whom hydrocephalus was found in the neonatal period, VP shunt was placed and transanal protrusion of the shunt catheter was observed in the follow-up. We aimed to discuss the complications of VP shunt and the importance of colon perforation among these.

\section{Case 1}

In the history of a male patient who presented to our emergency outpatient clinic at the age of 9 months with complaints of fever and restlessness, it was learned that he was born at term with a birth weight of $3000 \mathrm{~g}$, 
VP shunt was placed at the age of one month because of hydrocephalus and the shunt was changed at the 4th and 8th months becuase of shunt dysfunction. Physical examination findings were as follows: body weight: $9 \mathrm{~kg}$ (25-50p), height: $73 \mathrm{~cm}$ (50p), head circumference: 53 $\mathrm{cm}(>97 \mathrm{p})$, pallor was present. Other system findings were found to be normal. The laboratory findings were as follows: WBC: 21 400/mm³, CRP: 13,4 mg/dL, erythrocyte sedimentation rate: $82 \mathrm{~mm} / \mathrm{h}$. CSF sample findings were as follows: glucose: $37 \mathrm{mg} / \mathrm{dL}$, protein: $283 \mathrm{mg} / \mathrm{dL}$, cells: $93 / \mathrm{mm}^{3}$ lymphocytes. Shunt infection was considered in the patient. CSF and blood cultures were obtained and antibiotic treatment was started with a diagnosis of shunt infection. Cranial computarized tomography, complete urinary analysis and postero-anterior lung graphy were found to be normal. On the fifth day of hospitalization, his fever dropped, his general status, vital findings and CSF findings improved. On the 9th day of hospitalization, his general status detoriorated again and fever and convulsion occured. The patient was admitted to the intensive care unit. The laboratory tests were as follows: WBC: 28 000/ $\mathrm{mm}^{3}$, CRP: $15.7 \mathrm{mg} / \mathrm{dL}$. CSF findings were as follows: color: xanthochromic, glucose: 1mg/dL, protein: $726 \mathrm{mg} /$ $\mathrm{dL}$; on cell count, abundant lymphocytes and PNL were observed. E.coli grew in CSF culture. Antibotic treatment was adjusted and transanal protrusion of the shunt was observed on the $20^{\text {th }}$ day of hospitalization (Picture 1).

The shunt of the patient was removed with surgical operation. After an antibiotic treatment of approximately two months the clinical and laboratory findings improved and the shunt was placed again.

\section{Case 2}

A diagnosis of hydrocephalus was made in the 6th month in the prenatal period in a 4-year-old female patient who was followed up with a diagnosis of congenital hydrocephalus. At the age of 1.5 years while he was being followed up with a diagnosis of congenital hydrocephalus, convulsion which lasted approximately for 4 hours was observed. After this convulsion hydrocephalus increased gradually and the first VP shunt was placed at the age of two years. One month later shunt infection occured and his shunt was removed. One year later, VP shunt was placed for the second time at the age of three years. Afterwards, he was followed up in the Intensive Care Unit for 6 months because of dental abscess and pneumonia which developed during hospitalization. Tracheostomy was performed in October 2010, since he could not be seperated from the ventilator and the patient was discharged with a home type mechanical ventilator.

He had no complaint during the follow-up at home. He presented to our clinic when the family noticed that the VP shunt exited from the rectum. On presentation, his general status was moderate, he had tracheostomy and was connected to a home type mechanical ventilator. The patient who was quadriplegic had no relation with his surroundings. Abdominal examination was found to be normal. Examination of the other systems was found to be normal. It was observed that the tip of the ventriculo-peritoneal shunt exited from the rectum (Picture 2). Complete blood count and other biochemical tests were found to be normal. On direct abdominal graphy at a standing position (Picture 3 ), it was found that the VP shunt exited from the rectum by perforating the colon. The tip which exited outside was held with a clemp. In this way, preparation was made for operation. During the operation, the place where the upper part of the shunt entered the

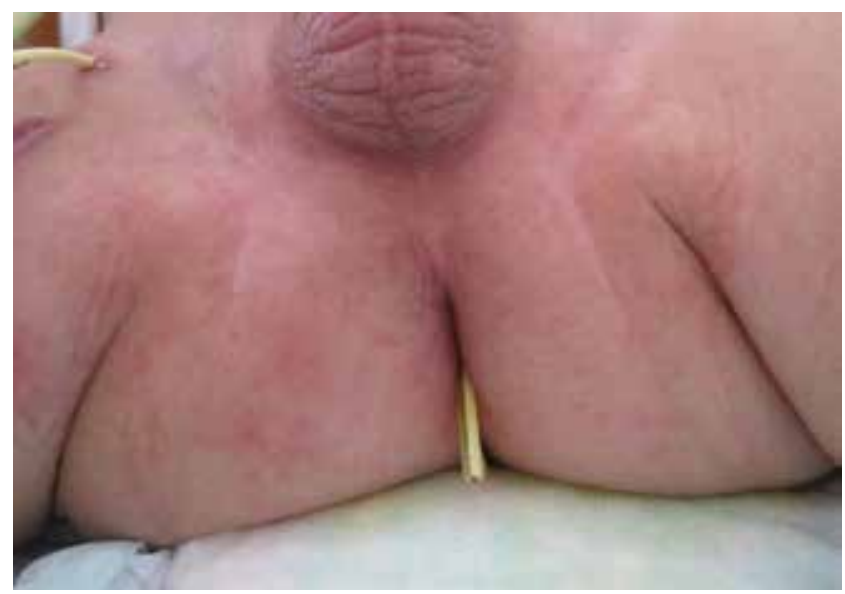

Picture 1. Protrusion of the end of the shunt from the anal region

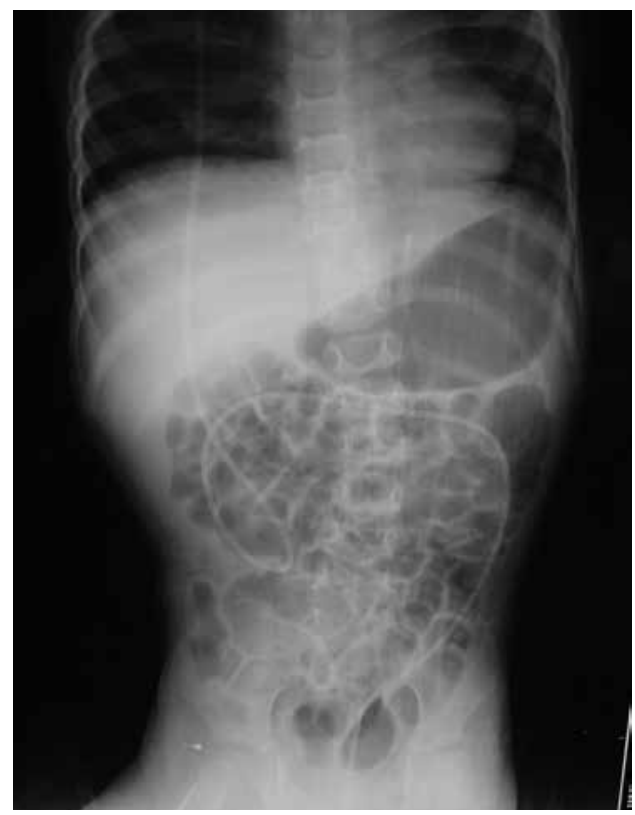

Picture 2. Protrusion of the end of the shunt from the anal region. 
peritoneum was found. The shunt was cut with scissors here and the tip which was held with a clemp was removed by pulling from the anus. In this way, the shunt which exited from the rectum was not allowed to contaminate the abdomen retrogradely. Afterwards, the cranial tip of the shunt was also removed. Oral intake was discontinued for three days to allow closure of the defect due to the shunt in the rectum. The wide-spectrum antibiotic which was initiated before the operation was continued for 10 days. The patient was started to be fed orally on the $4^{\text {th }}$ day, since no finding of peritonitis was present. A new VP shunt was placed in the $3^{\text {rd }}$ week.

\section{Discussion}

Ventriculoperitoneal shunt surgery has been used as a regular treatment for more than a hundred years in treatment of hydrocephalus (6). However, shunts may lead to complications which cause to morbidity and even mortality. The main complications which may be observed after ventriculoperitoneal shunt placement include ventriculitis, meningitis, sepsis, bowel perforation, various abdominal complications including development of pseudocyst and enterance of the peritoneal catheter into the scrotum, umblicus, vagina or gastrointestinal system $(11,12)$. Wilson and Bertan (7) reported two patients in whom complication related with VP shunt developed in 1966 for the first time. The most common complications include shunt dysfunction and shunt infections (13). Among all complications, abdominal complications are observed with a rate of $25 \%$ and may occur in a few months to a few years after placement of the shunt (11).

Hollow organ perforation which is a rare complication of ventriculo-peritoneal shunt is observed substantially rarely $(0.01 \%-0.07 \%)(6,7,8,9,10)$. Snow et al. (14) reported a mortality rate of $15 \%$ in their literature review which included 32 subjects. Perforation may occur in any part of the gastrointestinal system, but it is reported to occur frequently in the colon (15).

In most of the studies in the literature, it is reported that it is not known how intestinal perforations related with VP shunt occur (16). It is proposed that the catheter leads to perforation by pressing and abrading the colon wall in time $(5,17)$. Patients with myelomeningocele and congenital hydrocephalus are prone to perforation because of the weakness of the intestinal wall due to weak innervation (6). Silicon allergy can also be shown as a cause of intestinal perforation (13). In both of our patients, there was a history of congenital hydrocephalus and operation with a diagnosis of shunt dysfunction. Weakening of the colonic wall due to ventriculo-peritoneal shunt is considered as the cause of perforation in both of our patients.

The main reasons of presentation in patients who develop intestinal perforation include acute abdominal findings, ventriculitis, meningoencephalitis and subdural abscess. The common symptoms include abdominal pain, vomiting and fever (12). Vinchon et al. (16) reported that fever was observed with a rate of $73.7 \%$ and acute abdominal findings were observed with a rate of $47.4 \%$ in perforation. Sometimes, it may be clinically silent. Recovery has been reported to be excellent in patients who are found in the asymptomatic period (18). When we assessed our patients in terms of signs and symptoms, we found that they showed difference in accordance with the literature. Meningitis was found in our first patient and our second patient was asymtomatic.

The most commonly found microorganisms are enteric gram negative organisms in CSF culture examinations performed in patients with intestinal perforation (6). Among these microorganisms, the most commonly found is Escherichia coli $(6,12,18)$. E.Coli was found in the CSF culture in our first patient.

Four types of treatment have been reported for treatment of intestinal perforation related with ventriculoperitoneal shunt. These include; 1) Minilaparotomy and revision of the pritoneal part of the shunt, 2) exploratory laparotomy and repair of intestinal perforation in selected cases, 3) removal of the shunt, external ventricular drainage, renewal of the shunt after antibiotherapy, 4) determination of the place of perforation and removal of the shunt using a flexible pediatric colonoscope (15). In both of our patients, the shunt was removed, external drainage was performed and the shunt was renewed after antibiotic treatment by neurosurgery.

Intestinal perforation with peritoneal shunt catheter is a neurosurgical emergency (5). If intestinal perforation is determined in an early and asymptomatic period and treatment is started early, response to treatment and prognosis are favorable. Otherwise, these complications may lead to fatal infectious complications in patients who are diagnosed in a late period (11). Conclusively, hollow organ perforation should be considered as a possible diagnosis in patients presenting with shunt dysfunction or meningitis findings. Growth of coliform bacteriae in CSF culture indicates intestinal perforation. Transanal protrusion of the catheter establishes a final diagnosis (19).

\section{References}

1. Lemire RJ. Neural tube defects. JAMA 1988; 259: 558-562.

2. Adams RD, Fischer CM, Hakim S, Ojeman RG, Sweet WH. Symptomatic occult hydrocephalus with 'normal' cerebrospinal fluidpressure. A treatable syndrome. N Engl J Med 1965; 273: 117-126.

3. Glees P, Voth D. Clinical and ultrastructural observations of maturing human frontal cortex, part I (biopsy material of hydrocephalic infants). Neurosurg Rev 1988; 11: 273-8.

4. Çırak B, Güven MB, Ceylan A, Çaksen H, Kıymaz N, Işık S. Neonatal hidrosefaliler. Van Tıp Dergisi 1999; 6 : 34-36. 
5. Hok-Nam Li, Tze-Ching Tan, Li HN, Tan TC, Cheung FC. Transanal protrusion of ventriculoperitoneal shunt. Surgical Practice 2008; 12: 93-96.

6. Sathyanarayana S, Wylen EL, Baskaya MK, Nanda A Spontaneous bowel perforation after ventriculoperitoneal shunt surgery: Case report and review of 45 cases. Surg Neurol 2000; 54: 388-396.

7. Abu-Dalu K, Pode D, Hadani M, Sahar A. Colonic complications of ventriculoperitoneal shunts. Neurosurgery 1983; 13: 167-169.

8. Guillen A, Costa JM, Castello I, Claramunt E, Cardona E. Complicación abdominal poco frecuente de las derivaciones ventriculoperitoneales. Neurocirugía 2002; 4: 401-404.

9. Bharti P, Kumar T, Bharti S. Rare shunt complication: Letter to editor. Neurol India 2002; 50: 108-109.

10. Sánchez MR, Cordón R, Girón RR. Prolapse of the ventriculoperitoneal shunt through the rectum. Cir Pediatr 1996; 9: $122-124$

11. Birbilis T, Zezos P, Liratzopoulos N, Oikonomou A, Karanikas M, Kontogianidis K, Kouklakis G. Spontaneous bowel perforation complicating ventriculoperitoneal shunt: A case report. Cases Journal 2009; 2: 8251.

12. Yüceer N, Şenoğlu M, Arda MN. Geç ventrikulo-peritoneal şant komplikasyonu: iki olguda peritoneal kateterin anal prolapsusu. Türk Nöroşirürji Dergisi 2004; 14: 133-136.
13. Akgün B, Aktaş EG, Erol FS, Kaplan M, Arıcı L. Ventrikuloperitoneal şant komplikasyonları: 75 olgunun değerlendirilmesi. FÜ Sağ Bil Derg 2008: 22: 69-72.

14. Snow RB, Lavyne MH, Fraser RAR. Colonic perforation by ventriculoperitoneal shunts. Surg Neurol 1986; 25: 173-177.

15. Ghritlaharey RK, Budhwani KS, Shrivastava DK, Gupta G, Kushwaha AS, Chanchlani R, Nanda M. Transanal protrusion of ventriculo-peritoneal shunt catheter with silent bowel perforation: Report of two cases in children. Pediatr Surg Int 2007; 23: 575580.

16. Vinchon M, Baroncini M, Laurent T, Patrick D. Bowel perforation caused by peritoneal shunt catheters: diagnosis and treatment. Neurosurgery 2006; 58: 76-82.

17. Brownlee JD, Brodley JS, Schaefer IK. Colonic perforation by ventriculoperitoneal shunt tubing: A case of suspected silicon allergy. Surg Neurol 1998; 49: 21-24.

18. Zhou F, Chen G, Zhang J. Bowel perforation secondary to ventriculoperitoneal shunt: Case report and clinical analysis. J Int Med Res 2007; 35: 926-929.

19. Ceran C, Karadağ Ö, Gürünlüoğlu K, Önal Ç. Kolon perforasyonu ve ventrikülo-peritoneal şantın anüsten protrüzyonu: iki olgu. İnönü Üniversitesi Tıp Fakültesi Dergisi 2006; 13: 271-273. 